\title{
SZOFTVER ÁLTAL DEFINIÁLT HÁLÓZATOK ÁTTEKINTÉSE
}

\section{OVERVIEW OF SOFTWARE DEFINED NETWORKS}

\author{
Agg Péter András ${ }^{1}$, Johanyák Zsolt Csaba ${ }^{2}$, Göcs László ${ }^{3}$. \\ Kecskeméti Föiskola, Gépipari és Automatizálási Müszaki Főiskola Kar, Informati- \\ ka Tanszék, Magyarország, 6000 Kecskemét, Izsáki út 10. Fax: +36-76-516-399 \\ lagg.peter@gamf.kefo.hu \\ 2 johanyak.csaba@gamf.kefo.hu \\ 3gocs.laszlo@gamf.kefo.hu
}

\begin{abstract}
Nowadays computer networks have to fulfil several essential requirements like ease of use, efficiency, security, easy manageability, as well as easy configurability. The concept of Software Defined Networking (SDN) has been developed especially for these purposes. It represents a new technology whose penetration is continuously growing. The novel idea in SDN is that it removes the control plane from network hardware and implements it in software. This solution creates the possibility of a dynamic programmatic access and a more flexible network administration. This paper gives an overview of the structure and key features of SDN as well as presents some advantages of its application
\end{abstract}

Keywords: SDN, Software-Defined Networking, OpenFlow, SDN layers

\section{Összefoglalás}

Az informatikai hálózatok megvalósítása során nagy hangsúlyt kell fektetni a könnyü kezelhetőségre, hatékonyságra, és a biztonságára. Fontos szempont még a könnyü felügyelhetőség és konfigurálhatóság. A Software Defined Networking (SDN) vagy szoftver által definiált hálózat paradigma pontosan ezt a lehetőséget nyújtja. Ez egy napjainkban egyre jobban elterjedt technológia, ami biztosítja azt, hogy az adatsík (fizikai eszközök egyszerü adattovábbítási feladat ellátása) és a vezérlő sík (irányítás felsőbb rétegböl) külön váljon, és ezáltal könnyebb legyen a hálózat megvalósítása, mind költséghatékonyság, mind optimalizálás szempontjából.

Kulcsszavak: SDN, szoftver által definiált hálózatok, OpenFlow, SDN rétegek

\section{Bevezetés}

A hálózati szolgáltatásokkal szemben nagyon sok elvárást támasztanak, hiszen a számítógépek közötti kommunikáció elengedhetetlen mai világban. Alapvető követelmény például egy egyszerü felhasználó számára a maximális rendelkezésre állás és a nagy adatátviteli sebesség. Ha egy iskolai hálózatot nézünk, akkor igényként megjele- nik még a skálázhatóság és a redundáns hálózatok fogalma is. Itt már nem hanyagolható el az alacsony költségen tartható üzemeltetés iránti elvárás sem.

A hálózati infrastruktúrák hátrányainak, hibáinak (decentralizálás, nem megfelelő védelem, nem teljesen hibamentes müködés, költség-hatékonyság) feloldására ma is vannak megoldások, amelyek részben leegyszerüsítik a konfigurálást. Ilyen például 
az OSI 2. rétegében müködő kapcsolóknál a virtuális helyi hálózat (virtual local area network - VLAN) definiálása.

A VLAN hálózati eszközök egy csoportja, amelynek tagjai úgy képesek kommunikálni egymással, mintha azonos szegmensbe tartoznának, miközben fizikailag több különböző szegmensben is elhelyezkedhetnek. A CISCO által kifejlesztett VLAN Trunking Protocol (virtuális trönkprotokoll - VTP) egy ügyfélkiszolgáló alapú üzenettovábbító protokoll, melynek segítségével egyszerre tudjuk konfigurálni a hálózat VLAN konfigurációjának azon részét, amely egy VTP tartományhoz tartozik [6]. Bár a VTP és más kiegészítő megoldások sokban könnyítik a tervezők és adminisztrátorok munkáját, de csak részfeladatokat oldanak meg.

A hálózati infrastruktúra koncepciójának teljes megújulását a szoftver által definiált hálózatok (Software-Defined Networking - SDN) [4] fogalmának megjelenése jelentette.

Cikkünkben ismertetjük az SDN architektúráját és kapcsolatát az OpenFlow protokollal. Kitérünk az SDN rétegeire, az ott használt megoldásokra, illetve ezek előnyeire is. Célunk annak bemutatása, hogy mennyire feltörekvő paradigma az SDN, illetve az, hogy alkalmazásának eredményeképpen mennyivel hatékonyabb lehet a hálózatunk müködtetése.

\section{Software-Defined Networking (SDN)}

A szoftver által definiált hálózat egyik legfontosabb jellemezője, hogy szétválasztja a vezérlési síkot (control plane) és az adatsíkot (data plane) (eszközsíkot) az eszközökben [5]. Azzal, hogy elkülöníti ezt a két síkot, a hálózati eszközök (kapcsolók, forgalomirányítók) egyszerü továbbító eszközökké válnak, és a vezérlés központosításra kerül, miáltal sokkal költséghatékonyabb lesz a rendszer, továbbá könnyebben megvalósítható a testreszabhatóság és optimalizálás is. A központosítás segítségével a hálózati rendszergazdának nem szükséges minden eszköz interfészén parancssorból (Command Line Interface - CLI) elvégeznie a konfigurálást, hanem csupán egyetlen kontroller beállítása elég a hálózat zavartalan müködtetéséhez. Ez természetesen nem azt jelenti, hogy fizikailag is központosítottá válik a rendszer.

Az 1. ábrán látható, hogy az új réteg segítségével elfedhetjük a hardver elemek és szolgáltatások különböző interfészeit, miáltal nagyobb rugalmasságot biztosíthatunk az adott hálózatnak.

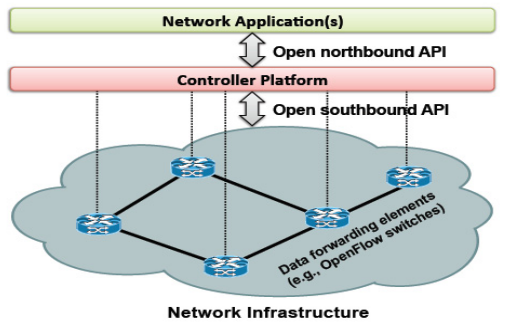

1. ábra. SDN architektúra nézete [3]

\section{SDN és az OpenFlow}

Az OpenFlow [4] egy kommunikációs protokoll, ami lehetőséget nyújt a hálózatok működésének felülírására, módosítására. A szabványt a Stanford és a Berkeley egyetemek oktatói készítették elsősorban a saját hálózati problémáik megoldására, de nagyon hamar elterjedt, pl. a Google is ezt használja.

Ez a viszonylag fiatal protokoll az iparban is egyre jobban teret hódít. A hálózati eszközök jelentős része támogatja az OpenFlow szabvánnyal való együttmüködést.

Az OpenFlow protokollnál a hálózati eszközök csak a csomag küldését és fogadását végzik, az útvonalválasztás egy felsőbb réteg segítségével történik. Ezáltal könnyen elkerülhetővé válnak a túlterhelé- 
sek. Egy központi kontroller valósítja meg logikát (pl. útvonalválasztást), így a hálózati eszközökre kevésbé leterhelő szerep hárul.

Az OpenFlow az SDN-ben megfogalmazott alapelveken túl (az adat és a vezérlő sík szétválasztása) egy teljes kommunikációs protokollt biztosít. Azokat a hálózati eszközöket, amelyek képesek az OpenFlow-t kezelni switch-eknek nevezzük. Ez nem azt jelenti, hogy ezek az eszközök kizárólag csak az OSI 2. rétegében müködnek. A kontroller segítségével tetszöleges funkciót oszthatunk ki nekik, és ennek megfelelően müködtethetjük azokat.

\section{SDN rétegei, jellemzői, lehetősé- gei}

Az SDN 3 fő réteget definiál (2. ábra). Ezek az adatsík (Data plane), a vezérlő sík (Control plane), és a menedzsmet sík (Management plane).

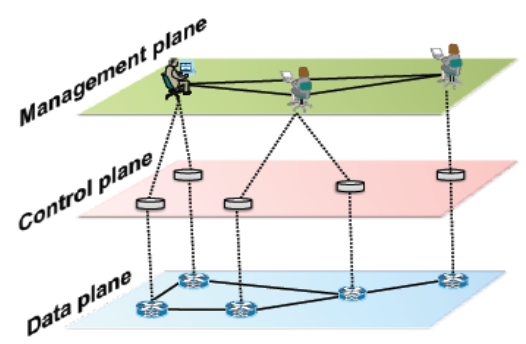

2. ábra. SDN hálózati funkciók rétegenként [3]

\subsection{Adatsík}

Az adatsík (Data Plane) réteg (3. ábra) biztosítja a hálózati csomagok mozgatását az egyes hálózati szegmensek vagy végpontok között. Az adatsík két fö részre bontható, ezek a hálózati infrastruktúra (Network Infrastructure) és a déli interész (Southbound interface)

A hálózati infrastruktúra gyakorlatilag megegyezik az korábbi hálózatok hálózati eszközeivel, azzal a kiegészítéssel, hogy az eszközöknek rendelkezni kell egy a felsőbb rétegek felé nyitó lehetőséggel, ami által vezérelhetők lehetnek. (pl.: OpenFlow protokoll). Ez a szabvány pontosan leírja, mit kell tenni a csomaggal [1].

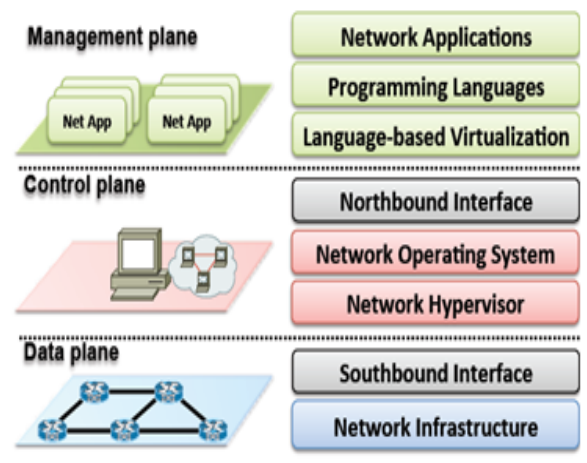

3. ábra. SDN tervezési architektúra [3]

A déli interfészek (Southbound API) hidat képeznek az adat és a vezérlő sík között. Bár erősen függnek a hardvertöl, de az OpenFlow protokoll elterjedésének köszönhetően, a gyártók kompatibilissé tették az eszközeiket, ami nagymértékben megkönynyítette a hatékony hálózati infrastruktúra kialakítását. A déli interfészek meghatározzák, és kezelik azokat az információkat, amelyek fontosak hálózati operációs rendszerek számára (adatküldés port, link változás után, útvonalváltozások jelzése, ismeretlen, kézbesítetlen csomagok hibái, stb.).

\subsection{Vezérlő sík}

A vezérlő sík egyik legfontosabb eleme a virtualizáció. A hálózati virtualizáció (Network Hypervisor)[5] nagymértékben csökkenti a költségeket, segíti a hálózati műveletek automatizálását [7]. Az itt használt hálózati virtualizációs programok megszüntetik a hagyományos hiányosságokat és az időigényes műveleteket használatát. Például szükségtelenné válik VLAN-ok vagy a hozzáférés szabályozó listák (Access Control List - ACL) beállítása. Az SDNalapú hálózati virtualizációs alkalmazás támogatja szabadon választott IP / MAC 
címzés rendszerek bevezetését, miközben egyidejüleg megoldja az automatikus hálózati konfigurációs feladatokat is. A hálózat virtualizációja kihasználja az OpenFlow protokoll adta lehetőségeket mind a fizikai mind a virtuális hálózati eszközök vonatkozásában.

A vezérlési síkban használt szoftver lehetővé teszi a dinamikus hozzáférést és az adminisztrációt. A hálózati rendszergazda egy központi vezérlő konzolon keresztül anélkül alakíthatja a forgalmat, hogy közvetlenül konfigurálnia kelljen az adott eszközt. Amennyiben szükséges, változtathat a prioritásokon, sőt blokkolhat bizonyos típusú csomagokat központilag, ami a biztonság és az ellenőrzés szempontjából is nagyon elönyös lehetöség.

A hálózati operációs rendszer (Network Operating Sytem) biztosítja a hálózati menedzsment problémáinak megoldását a központosított vezérlés terén. Így a fejlesztőnek már nem kell figyelnie az alacsonyabb szintekre [6].

Ebben a rétegben található az SDN másik kulcsfontosságú része északi interfész. Ellentétben a déli interfésszel, ahol már egy jól bevált protokoll létezik (OpenFlow), itt még nagyon sok a nyitott kérdés. Elsősorban a szoftveres kommunikáció a kulcsfontosságú, de ennek összetettsége miatt, még nem lehet konkrét szabványosított megoldást megnevezni.

\subsection{Menedzsment sík}

A harmadik rétegben (Management Plane) a menedzsment eszközök helyezkednek el. Míg a vezérlési síkon található összetevők megismerik, tanulják a hálózat konkrét felépítését, addig a menedzsment réteg feladata a pontos utasítások kiadása a vezérlés felé.

A mai eszközök egyedileg konfigurálhatók, melyekhez megfelelö szakember szükséges, mivel a hálózati konfiguráció során a legjelentősebb hibaforrás az emberi tényező.

\section{Következtetések}

Az SDN egy olyan technológia, ami jelentősen megkönnyítheti a hálózatok konfigurálását és müködtetését. Biztosítja az eddigi decentralizálás helyett a centralizálást, ami a rendszergazdák munkáját jelentősen egyszerüsítheti. Az általa használt rétegek, sokkal könnyebbé teszik a hálózat felügyeletét, ellenőrzését úgy, hogy az egyes eszközök konfigurációs beállításai automatizáltan jutnak érvényre.

Az SDN jövőbeni fejlesztései maximálisan elősegítik a korszerü hálózatok kiépülését. Az SDN rétegstruktúrája biztosítja, hogy az alsóbb rétegek elkülönüljenek a felsőbb rétegektől, ami biztosítja a centralizált, „könnyebb”, és biztonságosabb vezérlést.

\section{Köszönetnyilvánítás}

A kutatást támogatta a Gépipari Automatizálás Fejlesztésének Alapítványa.

\section{Szakirodalmi hivatkozások}

[1] Big switch network http://www.bigswitch.com/company/sdntechnology [Hozzáférés: 2016.01.27.]

[2] N. Gude, T. Koponen, J. Pettit, B. Pfaff, M. Casado, N. McKeown, and S. Shenker: NOX: towards an operating system for networks, Comp. Comm. Rev., 2008.

[3] Diego Kreutz, Member, IEEE, Fernando M. V. Ramos, Member, IEEE, Paulo Verissimo, Fellow, IEEE, Software-Defined Networking: A Comprehensive Survey

[4] A. Lara, A. Kolasani, and B. Ramamurthy, Network innovation using OpenFlow: A survey

[5] T. D. Nadeau and K. Gray, SDN: Software defined networks, 1st ed. O'Reilly, 2013.

[6] S. Schenker, The Future of Networking, and the Past of Protocols, October 2011. [Online]. Available: http://www.youtube.com/watch?v=YHeyuD 89n1Y [Hozzáférés: 2016. 01. 20.]

[7] Understanding VLAN Trunk Protocol (VTP) http://www.cisco.com/c/en/us/support/docs/1 an-switching/vtp/10558-21.html [Hozzáférés: 2015. 12. 22.] 